\title{
Temperature-robust neural activity using feedback control of ion channel expression
}

\author{
Timothy O'Leary", Eve Marder \\ From The Twenty Third Annual Computational Neuroscience Meeting: CNS*2014 \\ Québec City, Canada. 26-31 July 2014
}

Neural activity depends on the kinetic properties of ion channels expressed in neurons. Small changes in these properties can dramatically affect synaptic integration, membrane excitability and circuit function. Like all biochemical processes, the kinetics of ion channels have an exponential temperature dependence and the exponent (the ' $\mathrm{Q}_{10}$ ') differs several-fold between ion channel types within species [1-3]. In warm-blooded animals such as mammals, deviations in temperature of only a few degrees Celsius can thus disrupt neural activity and lead to loss of consciousness or death. However, cold blooded animals, including all invertebrates, manage to survive and function despite temperature fluctuations of tens of degrees Celsius [1]. How is this robustness achieved? One possibility is that the self-regulating, activity-dependent mechanisms that maintain neuronal properties in cold-blooded animals operate in a way that specifically gives rise to temperature robustness. In this work we develop a model of activity-dependent ion channel regulation that can produce stable neuronal activity in spite of underlying differences in the temperature dependence and density of conductances in model neurons. We use this model to explore the constraints that temperature-robustness imposes on self-regulating models and the resulting consequences for neuronal properties and circuit function.

\section{Acknowledgements \\ Funding: NIH Grant NS081013, Charles A King Trust.}

Published: 21 July 2014

\section{References}

1. Tang LS, Goeritz ML, Caplan JS, Taylor AL, Fisek M, Marder E: Precise temperature compensation of phase in a rhythmic motor pattern. PLOS biology 2010, 8(8).

\footnotetext{
* Correspondence: toleary@brandeis.edu
}

Volen Center for Complex Systems, Brandeis University, Waltham, MA 02454, USA

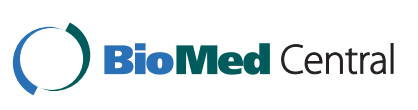

(0) 2014 O'Leary and Marder; licensee BioMed Central Ltd. This is an Open Access article distributed under the terms of the Creative Commons Attribution License (http://creativecommons.org/licenses/by/4.0), which permits unrestricted use, distribution, and reproduction in any medium, provided the original work is properly cited. The Creative Commons Public Domain Dedication waiver (http://creativecommons.org/publicdomain/zero/1.0/) applies to the data made available in this article, unless otherwise stated.
2. Tang LS, Taylor AL, Rinberg A, Marder E: Robustness of a rhythmic circuit to short-and long-term temperature changes. The Journal of Neuroscience 2012, 32(29).

3. Rinberg A, Taylor AL, Marder E: The effects of temperature on the stability of a neuronal oscillator. PLoS computational biology 2013, 9(1).

doi:10.1186/1471-2202-15-S1-P103

Cite this article as: O'Leary and Marder: Temperature-robust neural activity using feedback control of ion channel expression. BMC Neuroscience 2014 15(Suppl 1):P103.

Submit your next manuscript to BioMed Central and take full advantage of:

- Convenient online submission

- Thorough peer review

- No space constraints or color figure charges

- Immediate publication on acceptance

- Inclusion in PubMed, CAS, Scopus and Google Scholar

- Research which is freely available for redistribution Submit your manuscript at
www.biomedcentral.com/submit C BioMed Central 